\title{
Penerapan Model Pembelajaran Discovery Learning Muatan Matematika Sebagai Upaya Meningkatkan Hasil Belajar Siswa Di Kelas IV SDN 137/IX Petaling
}

\author{
Suyanto \\ Guru SDN 137/IX Petaling \\ Correspondence email: ysaja9193@gmail.com
}

\begin{abstract}
Abstrak. Penelitian ini bertujuan untuk mendapatkan informasi dan membahas tentang Penerapan Model Pembelajaran Discovery Learning Muatan Matematika Sebagai Upaya Meningkatkan Hasil Belajar Siswa di Kelas IV SDN 137/IX Petaling. Jenis penelitian ini adalah penelitian tindakan kelas. Penelitian ini dilaksanakan di SDN 137/IX Petaling pada semester genap tahun ajaran 2018/2019. Subjek dalam penelitian ini adalah siswa kelas IV SDN 137/IX Petaling dengan jumlah siswa 28 orang dengan jumlah laki-laki 18 orang dan perempuan sebanyak 10 orang. Prosedur penelitian ini meliputi perencanaan, pelaksanaan, pengamatan, dan refleksi. Penelitian ini dilaksanakan dalam dua siklus, masing-masing siklus terdiri dari dua kali pertemuan. Teknik yang digunakan dalam pengumpulan data adalah observasi, tes, catatan lapangan dan dokumentasi. Data di analisis melalui persentase dan reduksi data. Hasil penelitian ini menunjukkan bahwa hasil muatan Matematika siswa dalam proses pembelajaran meningkat dengan menggunakan model pembelajaran Discovery Learning dengan tindakan pemberian pujian.
\end{abstract}

Kata kunci: Hasil Belajar; Matematika; Discovery Learning; Pujian.

Abstract. This research aims to obtain information and discuss the Implementation of Discovery Learning Model of Mathematics Content as an effort to improve student learning outcomes in Grade IV SDN 137/IX Petaling. This type of research is class action research. This research was conducted at SDN 137/IX Petaling in the even semester of the 2018/2019 school year. The subjects in this study were grade IV students of SDN 137/IX Petaling with a total of 28 students with a male number of 18 men and 10 women. These research procedures include planning, implementation, observation, and reflection. The study was conducted in two cycles, each cycle consisting of two meetings. Techniques used in data collection are observations, tests, field records and documentation. Data is analyzed through percentage and data reduction. The results of this study show that the results of students' mathematics content in the learning process improved by using discovery learning models with the act of giving praise.

Keywords: Learning Outcomes; Mathematics; Discovery Learning; Praise.

\section{PENDAHULUAN}

Peraturan Menteri Pendidikan Nasional (Permendiknas) tahun 2006 tentang Standar Isi (SI) dan Standar Kelulusan (SKL) merumuskan bahwa pendidikan Nasional didasarkan pada pancasila Undang - undang Dasar Negara Republik Indonesia Tahun 1945. Peraturan tersebut berfungsi mengembangkan kemampuan dan membentuk watak serta peradaban bansa yang bermartabat dalam rangka mencerdaskan kehidupan bangsa yang bertujuan untuk mengembangkan potensi siswa agar menjadi manusia yang beriman dan bertaqwa kepada Tuhan Yang Maha Esa, berakhlak mulia, sehat, berilmu, cakap, kreatif, mandiri, dan menjadi warga Negara yang demokratis. Hal tersebut sejalan dengan Undang - undang nomor 20 tahun 2003 tentang sistem Pendidikan Nasional bahwa Pendidikan adalah usaha sadar bahwa terencana untuk mewujudkan suasana Belajar dan proses pembelajaran.

Agar peserta didik secara aktif mengembangkan potensi dirinya untuk memiliki kekuatan emosional dan Sepiritual keagamaan, pengendalian diri, kepribadian, kecerdasan, akhlak mulia, serta keterampilan yang diperlakukan dirinya, masyarakat, bangsa dan Negara.
Proses pembelajaran yang menarik danmemberikan kesan serta pengalaman secara langsung, sesuai dengan kehidupan dan kebutuhan aktual siswa ialah proses pembelajaran yang diharapkan saat ini. Kurikulum 2013 adalah sebuah kurikulum yang dikembangkan untuk meningkatkan kemampuan soft skills dan hard Skill yang berupa sikap, keterampilan, dan pengetahuan. Model Discovery Learning adalah suatu model untuk mengembangkan cara belajar siswa aktif dengan menemukan sendiri, menyelediki sendiri, maka hasil yang diperoleh akan setia dan tahan lama dalam ingatan, tidak akan mudah dilupakan siswa (Hosnan, 2014).

Sejauh ini pendidikan masih disominasi oleh pandangan bahwa pengetahuan sebagai perangkat fakta - fakta yang harus dihafal. Kelas masih berfokus pada guru sebagai sumber utama pengetahuan, kemudian ceramahmenjadi pilihan utama strategi belajar. Oleh karena itu, diperlukan sebuah strategi belajar yang tidak mengharuskan siswa menghafal fakta - fakta, tetapi sebuah strategi yang mendorong siswa mengontruksikan pengetahuan dibenak mereka sendiri. Ada kecenderungan dewasa ini untuk kembali pada pemikiran bahwa anak akan belajar lebih baik jika 
lingkungan belajar diciptakan alamiah. Belajar akan lebih bermakna jikan anak mengalami apa yang dipelajarinya, bukan mengetahuinya. Pembelajaran yang beorientasi target penguasaan materi terbukti berhasil dalam kompetensi jangka pendek, tetapi gagal dala membekali anak memecahkan persoalan dalam jangka panjang.

Berdasarkan hasil observasi bahwa diketahui hasil belajar siswa masih rendah dan belum maksimal. terlihat pada kegiatan yang berlangsung di dalam kelas belum mengacu pada pembelajaran yang aktif, efektif dan bermakna. Berdasarkan penjelasan diatas terlihat bahwa hasil belajar siswa kelas IV pada pelajaran Matematika di SDN 137/IX Petaling. Disamping permasalahan diatas yang menyebabkan rendahnya hasil belajar siswa antara lain : a) kurangnya minat siswa kelas IV 137/IX Petaling terhadap pembelajaran Matematika tema data dan pengukuran, b) model pembelajaran yang digunakan kurang bervariasi. Oleh karena itu, Penelitian ini bertujuan untuk mendapatkan informasi dan membahas tentang Penerapan Model Pembelajaran Discovery Learning Muatan Matematika Sebagai Upaya Meningkatkan Hasil Belajar Siswa di Kelas IV SDN 137/IX Petaling.

Konteks pendidikan, hampir semua aktivitas yang dilakukan adalah aktivitas belajar. Sumadi Suryabrata (2003) menjelaskan pengertian belajar dengan mengidentifikasikan ciri-ciri yang disebut belajar, yaitu belajara adalah aktivitas yang menghasillan perubahan pada diri individu yang belajar, baik aktual maupun potensial, perubahan itu pada pokoknya adalah diperolehnya kemampuan baru. yang berlaku dalam waktu relative lama, perubahan itu terjadi karena usaha. Belajar merupakan komponen dan ilmu pengetahuan yang berkenaan dengan tujuan menambah dan mengumpalkan sejumlah ilmu pengetahuan Sudirman (2004) menyatakan belajar adalah mencari makna, makna diciptakan oleh peserta didik dari apa yang mereka lihat, mereka dengar, dirasakan dan alami, jadi belajar sangat dipengaruhi oleh pengalaman objek dengan dunia fisik dan lingkungannya.

Menurut Skinner dalam Dimyanti dan Mudjiono (2013) belajar adalah suatu perilaku. Pada saat siswa belajar, maka responnya menjadi lebih baik dan sebaliknya, apabila siswa tidak belajar makan responnya menurun. Slameto (2003) belajar adalah suatu usaha yang dilakukan oleh seseorang untuk memperoleh suatu perubahan tingkah laku yang baru secara keseluruhan sebagai hasil pengalamannya sendiri dalam berinteraksi dengan lingkungannya. Menurut Slameto (2003) jenisjenis belajar sebagat berikut. Belajar Bagian, dilakukan oleh seseorang bila ia dihadapkan pada materi belajar yang bersifat luas. Dalam hal ini individu memecah seluruh materi pelajaran menjadi bagian-bagian yang satu sama lain berdiri sendiri. Belajar Dengan Wawasan, belajar seperti ini mengorganisasi pola-pola tingkah laku yang telah terbentuk menjadi satu tingkah laku yang ada hubungannya dengan penyelesaian suatu persoalan. Belajar Diskriminatif, suatu usaha untuk memilih beberapa sifat dan kemudian menjadikannya sebagai pedoman dalam bertingkah laku.

Pembelajaran adalah membelajarkan siswa menggunakan asas pendidikan maupun teori belajar merupakan penentu utama keberhasilan pendidikan. Pembelajaran merupakan proses komunikasi dua arah, mengajar dilakukan oleh pihak guru sebagai pendidik, sedangkan belajar dilakukan oleh peserta didik atau murid. Sudjana (2004) pembelajaran dapat diartikan sebagai upaya yang sistematik dan sengaja untuk menciptakan agar terjadi kegiatan interaksi edukatif antara dua pihak, yaitu antara peserta didik dan pendidik yang melakukan kegiatan pembelajaran. Warsita (2008) pembelajaran adalah suatu usaha untuk membuat peserta didik belajar atau suatu kegiatan untuk membelajarkan peserta didik.

Belajar dan mengajar merupakan konsep yang tidak dapat dipisahkan. Belajar merujuk pada apa yang harus dilakukan seseorang sebagai subyek dalam belajar berakhirnya suatu proses pembelajaran, maka siswa akan memperoleh suatu hasil belajar. Hasil belajar merupaka hasil dan suatu interaksi tindak belajar dan tindak mengajar Sedangkan mengajar merujuk pada apa yang seharusnya dilakukan seorang guru sebagai pengajar hasil belajar merupakan hal yang tidak dipandang dari dua sisi yaitu sisi siswa dan guru.

Hasil belajar dapat dilihat dari hasil nilai ulangan harian ulangan tengah semester dan nilai ulangan semester. Dalam penilaian tindakan kelas ini yang dimaksud dengan hasil belajar adalah hasil nilai ulangan harian yang dilakukan setelah proses pembelajaran dalam kompetensi tertentu. Menurut Anni (2004), hasil belajar merupakan perilaku yang diperoleh pembelajar setelah mengalami aktivitas belajar. Sedangkan Hamzah (2007) menyatakan bahwa: hasil belajar adalah perubahan perilaku yang relative menetap dalam diri seseorang sebagai akibat dan interaksi seseorang dengan lingkungannya. Berdasarkan pengertian hasil belajar tersebut dapat disimpulkan bahwa aspek-aspek perubahan perilaku tersebut tergantung pada apa yang di pelajari oleh pembelajar Kusnandar (2010) berpendapat bahwa hasil belajar adalah suatu perubahan pada individu yang belajar tidak hanya mengenai pengetahuan, tetapi juga membentuk kecakapan dan penghayatan dalam diri pribadi individu yang belajar. Hamalik (2001) menyatakan bahwa: hasil belajar adalah bila seseorang telah belajar akan terjadi perubahan tingkah laku pada orang tersebut, misalnya dari tidak tahu menjadi tahu dan tidak mengerti menjadi mengerti. Perubahan penilaku tersebut mencakup tiga ranah, yaitu kognitif efektif, dan psikomotor.

Matematika adalah ilmu tentang logika mengenai bentuk, susunan, besaran, dan konsep- 
konsep yang berhubungan satu dengan yang lainnya dengan jumlah yang banyak yang terbagi dalam tiga bidang yaitu aljabar, analisis, dan geometri. Dari pendapat beberapa tokoh di atas dapat disimpulkan bahwa matematika adalah pola berfikir, pola mengorganisasikan dan pembuaktian yang logik mengenai bentuk, susunan, besaran, dan konsepkonsep yang berhubungan. Matematika sangat penting dalam kehidupan. Bahkan setiap hari matematika digunakan oleh manusia dalam kehidupannya dalam mengitung belanja, mengukur, dan lain sebagainya. Mengingat betapa pentingnya matematika dalam kehidupan manusia, maka matematika perlu dikenalkan sedini mungkin. Dalam Pendidikan anak usia dini, matematika yang memiliki berbagai komponen dikenalkan dengan cara yang sesuai dengan karakteristik dan kemampuan anak. Piaget, Jean \& Inhelder, Barbel (2010), anak yang berada di bangku Taman Kanakkanak yang berusia 4-6 tahun yang dalam tahap perkembangan kognitifnya berada pada tahap praoperasional, pada umumnya dikenalkan matematika seperti Bilangan (number), Konservasi (conservation), Seriasi/Pengurutan (seriation), Klasifikasi (classification), Jarak (distance), Waktu dan kecepatan, Pola (pattern), dan Pengukuran (measurement).

Model Discovery Learning adalah memahami konsep, arti dan hubungan. Melalu proses intutif untuk akhirnya sampai kepada suatu kesimpulan (Budiningsih) Discovery terjadi bila individu terlibat, terutama dalam penggunaan proses mentalnya untuk menemukan beberapa konsep dan prinsip. Discovery dilakukan melalui observasi, klasifikasi, pengukuran, prediksi, penentuan dan inferi Disimpulkan bahwa model Discovery Learning adalah suatu model pembelajaran yang menitik beratkan pada aktivitas siswa, sementara guru hanya sebagai pembimbing/fasilitator yang mengarahkan siswa menemukan konsep dalil dan prosedur.

Model Discovery Learning adalah memahami konsep, arti, dan hubungan, melalui proses intutif untuk akhimya sampai kepada suatu kesimpalan (Budiningsth) Discovery terjadi bila individu terlibat, terutama dalam penggunaan proses mentalnya untuk menemukan beberapa konsep dan prinsip. Discovery dilakukan melalui observasi, klasifikasi, pengukuran, prediksi, penentuan dan inferi. Disimpulkan bahwa model Discovery Learning adalah suatu model pembelajaran yang menitik beratkan pada aktivitas siswa, sementara guru hanya sebagai pembimbing fasilitator yang mengarahkan siswa menemukan konsep dalil dan prosedur.

Dengan teknik tersebut, siswa dibiarkan menemukan sendiri atau mengalami proses mental sendiri, guru hanya membimbing dan memberikan instruksi. Dengan demikian, pembelajaran Discovery ialah suatu pembelajaran yang melibatkan siswa dalam proses kegiatan mental melalui tukar pendapat, dengan berdiskusi, membaca sendiri dan mencoba sendiri. Metode Discovery Learning sebagai sebuah teori belajar dapat didefinisikan sebagai belajar yang terjadi bila pelajar tidak disajikan dengan pelajaran dalam bentuk finalnya, tetapi diharapkan untuk mengorganisasi sendiri. Jadi pengertian model Discovery Learning yang sudah dibahas oleh para pendapat di atas yaitu suatu proses pembelajaran dimana siswa secara aktif memperoleh pengetahuan yang belum diketahuinya itu tidak melalui pemberitahuan, tetapi mereka menemukannya sendiri.

\section{METODE}

\section{Bentuk penelitian}

Penelitian ini merupakan penelitian tindakan kelas (PTK) dengan tujuan untuk memperbaiki dan meningkatkan mutu praktek-praktek pembelajaran. Menurut Arikunto (2002) bahwa penelitian tindakan kelas adalah penelitian tindakan (action research) yang dilakukan dengan tujuan memperbaiki mutu praktek pembelajaran di kelas.

Penelitian tindakan kelas dilaksanakan dalam bentuk siklus berulang yang didalamnya terdapat empat tahap utama yaitu perencanaan, tindakan/pelaksanaan, pengamatan/observasi dan refleksi.

\section{Subjek penelitian}

Penelitian ini dilaksanakan di SDN 137/IX Petaling pada semester genap tahun ajaran 2018/2019. Subjek dalam penelitian ini adalah siswa IV SDN 137/IX Petaling dengan jumlah siswa 28 orang dengan jumlah laki-laki 18 orang dan perempuan sebanyak 10 orang.

\section{Prosedur penelitian}

Prosedur penelitian terdiri dari dua siklus dengan tiap siklus dua kali pertemuan dengan masing-masing siklus empat tahap pelaksanaan mulai dari perencanaan, pelaksanaan, observasi dan refleksi.

\section{Istrumen Penelitian}

Pengumpulan data dalam penelitian ini dilakukan dengan menggunakan teknik catatan lapangan, lembar kerja siswa, tes tertulis, dan dokumen.

\section{Teknik Pengumpulan data}

Analisis data dalam penelitian ini melalui paparan data, dan penyimpulan hasil analisis. Untuk menghitung persentasi hasil belajar siswa peneliti menggunakan rumus:

Ketercapaian indikator siswa $=\frac{\text { skor yang diperoleh }}{\text { skor maksimal }} \times 100$ 


\section{HASIL DAN PEMBAHASAN \\ Siklus I \\ Perencanan}

Persiapan yang dilakukan pada perencanaan siklus 1 adalah Mempersiapkan lembar observasi aktifitas siswa, Menentukan materi yang akan dilaksanakan pada waktu penelitian agar mengetahui kompetensi dasar yang akan disampaikan kepada siswa dalam pembelajaran, Mempersiapkan silabus, Membuat Rencana Pelaksanaan pembelajaran (RPP) yang bercirikan pembelajaran dengan menggunakan Model pembelajaran Discovery Learning, dan Mempersiapkan media pembelajaran yang akan dipakai.

\section{Pelaksanaan}

\section{Pertemuan Pertama}

Pertemuan pertama dilaksanakan pada Senin tanggal 4 Februari 2019 pada jam ke 1 dan 2 dengan materi pokok Data dan Pengukuran. Kegiatan pembelajaran diawali dengan pendahuluan, kegiatan inti dan penutup. Pada kegiatan pendahuluan ini diawali dengan Melakukan pembukaan dengan salam pembuka dan berdoa untuk memulai pembelajaran. Memeriksa kehadiran peserta didik. Menyiapkan fisik dan psikis peserta didik dalam mengawali kegiatan pembelajaran. Mengaitkan materi/tema/kegiatan pembelajaran yang akan dilakukan dengan pengalaman peserta didik dengan materi/tema/kegiatan sebelumnya, Mengingatkan kembali materi prasyarat dengan bertanya. Mengajukan pertanyaan yang ada keterkaitannya dengan pelajaran yang akan dilakukan. Memberikan gambaran tentang manfaat mempelajari pelajaran yang akan dipelajari. Apabila materi/tema/projek ini kerjakan dengan baik dan sungguh-sungguh ini dikuasai dengan baik, maka peserta didik diharapkan dapat menjelaskan tentang pengertian Data. Menyampaikan tujuan pembelajaran pada pertemuan yang berlangsung dan Mengajukan pertanyaan. Setelah itu Memberitahukan materi pelajaran yang akan dibahas pada pertemuan saat itu. Memberitahukan tentang kompetensi inti, kompetensi dasar, indikator, dan KKM pada pertemuan yang berlangsung. Pembagian kelompok belajar dan Menjelaskan mekanisme pelaksanaan pengalaman belajar sesuai dengan langkah-langkah pembelajaran. pertemuan yang berlangsung. Kemudian Pembagian kelompok belajar menjelaskan mekanisme pelaksanaan pengalaman belajar sesuai dengan langkah-langkah pembelajaran.

Dalam kegiatan inti Peserta didik diberi motivasi atau rangsangan untuk memusatkan perhatian pada topik Menafsirkan sebuah datadengan cara Melihat tanpa atau dengan alat Mengamati Lembar kerja, pemberian contoh-contoh materi/soal untuk dapat dikembangkan peserta didik, dari media interaktif, dsb yang berhubungan dengan Menafsirkan sebuah data. Membaca Dilakukan di rumah sebelum kegiatan pembelajaran berlangsung, materi dari buku paket atau buku-buku penunjang lain, dari internet/materi yang berhubungan denganMenafsirkan sebuah data. Pemberian materi oleh guru yang berkaitan dengan Menafsirkan sebuah data. Penjelasan pengantar kegiatan/materi secara garis besar/global tentang materi pelajaran mengenai : Menafsirkan sebuah data untuk melatih kesungguhan, ketelitian, mencari informasi. Guru memberikan kesempatan pada peserta didik untuk mengidentifikasi sebanyak mungkin pertanyaan yang berkaitan dengan gambar yang disajikan dan akan dijawab melalui kegiatan belajar, contohnya Mengajukan pertanyaan tentang Menafsirkan sebuah datayang tidak dipahami dari apa yang diamati atau pertanyaan untuk mendapatkan informasi tambahan tentang apa yang diamati (dimulai dari pertanyaan faktual sampai ke pertanyaan yang bersifat hipotetik) untuk mengembangkan kreativitas, rasa ingin tahu, kemampuan merumuskan pertanyaan untuk membentuk pikiran kritis yang perlu untuk hidup cerdas dan belajar sepanjang hayat. Peserta didik mengumpulkan informasi yang relevan untuk menjawab pertanyan yang telah diidentifikasi melalui kegiatan. mengunjungi laboratorium komputer perpustakaan sekolah untuk mencari dan membaca artikel tentang Menafsirkan sebuah data.

Pada akhir proses belajar mengajar atau kegiatan penutup, Peserta didik Membuat rangkuman/simpulan pelajaran.tentang point-point penting yang muncul dalam kegiatan pembelajaran yang baru dilakukan. Melakukan refleksi terhadap kegiatan yang sudah dilaksanakan. Sementara itu Guru Memeriksa pekerjaan siswa yang selesai langsung diperiksa. Peserta didik yang selesai mengerjakan projek dengan benar diberi paraf serta diberi nomor urut peringkat, untuk penilaian projek. Kemudian Memberikan penghargaan kepada kelompok yang memiliki kinerja dan kerjasama yang baik. Merencanakan kegiatan tindak lanjut dalam bentuk tugas kelompok/ perseorangan (jika diperlukan). Mengagendakan pekerjaan rumah. Menyampaikan rencana pembelajaran pada pertemuan berikutnya

\section{Pertemuan kedua}

Dalam pertemuan kedua yang dilaksanakan hari Rabu tanggal 6 Februari 2019 dengan materi Data dan pengukuran. Kegiatan pembelajaran diawali dengan pendahuluan, kegiatan inti dan penutup. Pada kegiatan pendahuluan ini diawali dengan Melakukan pembukaan dengan salam pembuka dan berdoa untuk memulai pembelajaran. Memeriksa kehadiran peserta didik. Menyiapkan fisik dan psikis peserta didik dalam mengawali kegiatan pembelajaran. Mengaitkan materi/tema/kegiatan pembelajaran yang akan dilakukan dengan pengalaman peserta didik dengan materi/tema/kegiatan sebelumnya, Mengingatkan kembali materi prasyarat dengan bertanya. Mengajukan 
pertanyaan yang ada keterkaitannya dengan pelajaran yang akan dilakukan. Memberikan gambaran tentang manfaat mempelajari pelajaran yang akan dipelajari. Apabila materi/tema/projek ini kerjakan dengan baik dan sungguh-sungguh ini dikuasai dengan baik, maka peserta didik diharapkan dapat menjelaskan tentang pengertian Data. Menyampaikan tujuan pembelajaran pada pertemuan yang berlangsung dan Mengajukan pertanyaan. Setelah itu Memberitahukan materi pelajaran yang akan dibahas pada pertemuan saat itu. Memberitahukan tentang kompetensi inti, kompetensi dasar, indikator, dan KKM pada pertemuan yang berlangsung. Pembagian kelompok belajar dan Menjelaskan mekanisme pelaksanaan pengalaman belajar sesuai dengan langkah-langkah pembelajaran. pertemuan yang berlangsung. Kemudian Pembagian kelompok belajar menjelaskan mekanisme pelaksanaan pengalaman belajar sesuai dengan langkah-langkah pembelajaran.

Dalam kegiatan inti Peserta didik diberi motivasi atau rangsangan untuk memusatkan perhatian pada topik Menafsirkan sebuah data dengan cara Melihat tanpa atau dengan alat Mengamati Lembar kerja, pemberian contoh-contoh materi/soal untuk dapat dikembangkan peserta didik, dari media interaktif, dsb yang berhubungan dengan Menafsirkan sebuah data. Membaca Dilakukan di rumah sebelum kegiatan pembelajaran berlangsung, materi dari buku paket atau buku-buku penunjang lain, dari internet/materi yang berhubungan dengan Menafsirkan sebuah data. Pemberian materi oleh guru yang berkaitan dengan Menafsirkan sebuah data. Penjelasan pengantar kegiatan/materi secara garis besar/global tentang materi pelajaran mengenai Menafsirkan sebuah data untuk melatih kesungguhan, ketelitian, mencari informasi. Guru memberikan kesempatan pada peserta didik untuk mengidentifikasi sebanyak mungkin pertanyaan yang berkaitan dengan gambar yang disajikan dan akan dijawab melalui kegiatan belajar, contohnya Mengajukan pertanyaan tentang Menafsirkan sebuah datayang tidak dipahami dari apa yang diamati atau pertanyaan untuk mendapatkan informasi tambahan tentang apa yang diamati (dimulai dari pertanyaan faktual sampai ke pertanyaan yang bersifat hipotetik) untuk mengembangkan kreativitas, rasa ingin tahu, kemampuan merumuskan pertanyaan untuk membentuk pikiran kritis yang perlu untuk hidup cerdas dan belajar sepanjang hayat. Peserta didik mengumpulkan informasi yang relevan untuk menjawab pertanyan yang telah diidentifikasi melalui kegiatan. mengunjungi laboratorium komputer perpustakaan sekolah untuk mencari dan membaca artikel tentang Menafsirkan sebuah data.

Pada akhir proses belajar mengajar, Peserta didik Membuat rangkuman/simpulan pelajaran.tentang pointpoint penting yang muncul dalam kegiatan pembelajaran yang baru dilakukan. Melakukan refleksi terhadap kegiatan yang sudah dilaksanakan. Sementara itu Guru Memeriksa pekerjaan siswa yang selesai langsung diperiksa. Peserta didik yang selesai mengerjakan projek dengan benar diberi paraf serta diberi nomor urut peringkat, untuk penilaian projek. Kemudian Memberikan penghargaan kepada kelompok yang memiliki kinerja dan kerjasama yang baik. Merencanakan kegiatan tindak lanjut dalam bentuk tugas kelompok/ perseorangan (jika diperlukan). Mengagendakan pekerjaan rumah. Menyampaikan rencana pembelajaran pada pertemuan berikutnya.

\section{Observasi}

Berikut ini adalah deskripsi data hasil pengamatan hasil belajar peserta didik di kelas SDN 137/IX Petaling pada siklus I. Adapun data hasil penelitian pada siklus I adalah sebagai berikut:

Tabel 1. Rekapitulasi Hasil Tes Formatif Pada Siklus I

\begin{tabular}{lll}
\hline No. & Uraian & Siklus I \\
\hline 1. & Nilai rata-rata tes formatif & 65,35 \\
2. & Jumlah peserta didik yang tuntas belajar & 15 \\
3. & Persentase ketuntasan belajar & $53,57 \%$ \\
\hline
\end{tabular}

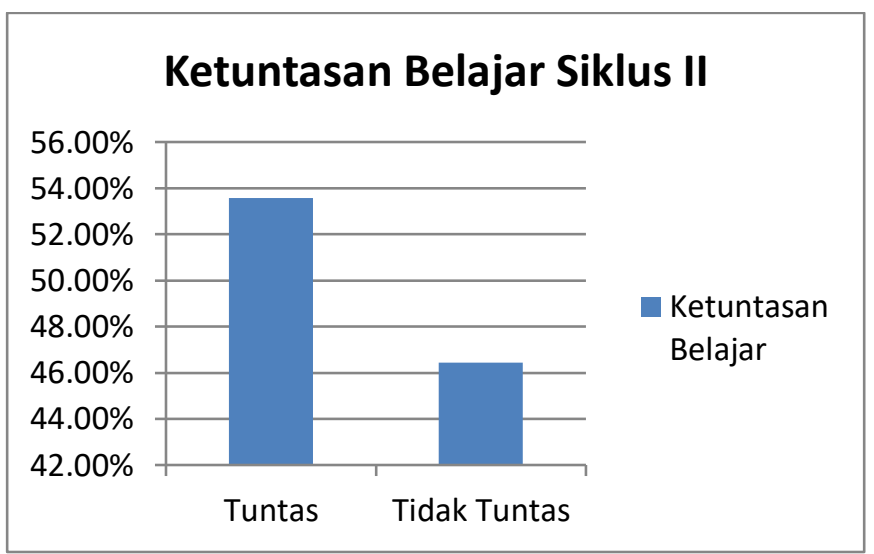

Gambar 1. Persentase Hasil Ketuntasan Belajar Siklus I

Dari tabel di atas dapat dijelaskan bahwa dengan menerapkan model pembelajaran Discovery Learning diperoleh nilai rata-rata hasil belajar siswa adalah 65,35 dan ketuntasan belajar mencapai 53,57\% atau ada 15 siswa dari 28 siswa sudah tuntas belajar dan 13 siswa $46.43 \%$ yang belum tuntas. Hasil tersebut menunjukkan bahwa pada siklus pertama secara klasikal siswa belum tuntas belajar, karena siswa yang memperoleh nilai $\geq 65$ hanya sebesar $53,57 \%$ lebih kecil dari persentase ketuntasan yang dikehendaki yaitu $80 \%$. Hal ini disebabkan karena siswa masih merasa baru dan belum mengerti apa yang dimaksudkan dan digunakan guru dengan menerapkan model pembelajaran Discovery Learning. 


\section{Siklus II \\ Perencanaan}

Persiapan yang dilakukan pada perencanaan siklus II adalah Mempersiapkan lembar observasi aktifitas siswa, Menentukan materi yang akan dilaksanakan pada waktu pembelajaran agar mengetahui kompetensi dasar yang akan disampaikan kepada siswa dalam pembelajaran. Mempersiapkan silabus (lampiran), Membuat Rencana Pelaksaan pembelajaran (RPP) yang bercirikan pembelajaran dengan menggunakan Model pembelajaran Discovery Learning. Mempersiapkan media pembelajaran yang akan dipakai, Membuat soal test hasil belajar siklus. Dan yang terakhir Membuat Kunci tes Hasil belajar siklus II

\section{Pelaksanaan}

\section{Pertemuan Pertama}

Pertemuan pertama dilaksanakan pada hari Senin tanggal 11 Februari 2019 pada jam ke 1 dan 2. Materi yang dibahas pada pertemuan pertama mengenai membedakan bahasa surat dinas dengan surat lainya. Kegiatan pembelajaran diawali dengan pendahuluan, kegiatan inti dan penutup. Pada kegiatan pendahuluan ini diawali dengan Melakukan pembukaan dengan salam pembuka dan berdoa untuk memulai pembelajaran. Memeriksa kehadiran peserta didik. Menyiapkan fisik dan psikis peserta didik dalam mengawali kegiatan pembelajaran. Mengaitkan materi/tema/kegiatan pembelajaran yang akan dilakukan dengan pengalaman peserta didik dengan materi/tema/kegiatan sebelumnya, Mengingatkan kembali materi prasyarat dengan bertanya. Mengajukan pertanyaan yang ada keterkaitannya dengan pelajaran yang akan dilakukan. Memberikan gambaran tentang manfaat mempelajari pelajaran yang akan dipelajari. Apabila materi/tema/projek ini kerjakan dengan baik dan sungguh-sungguh ini dikuasai dengan baik, maka peserta didik diharapkan dapat menjelaskan tentang pengertian Data. Menyampaikan tujuan pembelajaran pada pertemuan yang berlangsung dan Mengajukan pertanyaan. Setelah itu Memberitahukan materi pelajaran yang akan dibahas pada pertemuan saat itu. Memberitahukan tentang kompetensi inti, kompetensi dasar, indikator, dan KKM pada pertemuan yang berlangsung. Pembagian kelompok belajar dan Menjelaskan mekanisme pelaksanaan pengalaman belajar sesuai dengan langkah-langkah pembelajaran. pertemuan yang berlangsung. Kemudian Pembagian kelompok belajar. Menjelaskan mekanisme pelaksanaan pengalaman belajar sesuai dengan langkah-langkah pembelajaran.

Dalam kegiatan inti Peserta didik diberi motivasi atau rangsangan untuk memusatkan perhatian pada topik Menafsirkan sebuah datadengan cara Melihat tanpa atau dengan alat Mengamati Lembar kerja, pemberian contoh-contoh materi/soal untuk dapat dikembangkan peserta didik, dari media interaktif, dsb yang berhubungan dengan Menafsirkan sebuah data. Membaca Dilakukan di rumah sebelum kegiatan pembelajaran berlangsung, materi dari buku paket atau buku-buku penunjang lain, dari internet/materi yang berhubungan denganMenafsirkan sebuah data. Pemberian materi oleh guru yang berkaitan dengan Menafsirkan sebuah data. Penjelasan pengantar kegiatan/materi secara garis besar/global tentang materi pelajaran mengenai : Menafsirkan sebuah data untuk melatih kesungguhan, ketelitian, mencari informasi. Guru memberikan kesempatan pada peserta didik untuk mengidentifikasi sebanyak mungkin pertanyaan yang berkaitan dengan gambar yang disajikan dan akan dijawab melalui kegiatan belajar, contohnya Mengajukan pertanyaan tentang Menafsirkan sebuah datayang tidak dipahami dari apa yang diamati atau pertanyaan untuk mendapatkan informasi tambahan tentang apa yang diamati (dimulai dari pertanyaan faktual sampai ke pertanyaan yang bersifat hipotetik) untuk mengembangkan kreativitas, rasa ingin tahu, kemampuan merumuskan pertanyaan untuk membentuk pikiran kritis yang perlu untuk hidup cerdas dan belajar sepanjang hayat. Peserta didik mengumpulkan informasi yang relevan untuk menjawab pertanyan yang telah diidentifikasi melalui kegiatan. mengunjungi laboratorium komputer perpustakaan sekolah untuk mencari dan membaca artikel tentang Menafsirkan sebuah data. Di akhir pembelajaran guru memberitahu hasil ulangan pada siklus I, setelah itu guru memberikan pujian bagi siswa yang mencapai nilai KKM dan bagi siswa yang mendaptkan nilai ulangan harian tertinggi.

Pada akhir proses belajar mengajar atau kegiatan penutup, Peserta didik Membuat rangkuman/simpulan pelajaran.tentang point-point penting yang muncul dalam kegiatan pembelajaran yang baru dilakukan. Melakukan refleksi terhadap kegiatan yang sudah dilaksanakan. Sementara itu Guru Memeriksa pekerjaan siswa yang selesai langsung diperiksa. Peserta didik yang selesai mengerjakan projek dengan benar diberi paraf serta diberi nomor urut peringkat, untuk penilaian projek. Kemudian Memberikan penghargaan kepada kelompok yang memiliki kinerja dan kerjasama yang baik. Merencanakan kegiatan tindak lanjut dalam bentuk tugas kelompok/ perseorangan (jika diperlukan). Mengagendakan pekerjaan rumah. Menyampaikan rencana pembelajaran pada pertemuan berikutnya

\section{Pertemuan kedua}

Dalam pertemuan kedua yang dilaksanakan hari Rabu tanggal 13 Februari 2019 pada jam ke 1 dan 2 dengan materi Data dan pengukuran. Kegiatan pembelajaran diawali dengan pendahuluan, kegiatan inti dan penutup. Pada kegiatan pendahuluan ini diawali dengan Melakukan pembukaan dengan salam pembuka dan berdoa untuk memulai pembelajaran. Memeriksa 
kehadiran peserta didik. Menyiapkan fisik dan psikis peserta didik dalam mengawali kegiatan pembelajaran. Mengaitkan materi/tema/kegiatan pembelajaran yang akan dilakukan dengan pengalaman peserta didik dengan materi/tema/kegiatan sebelumnya, Mengingatkan kembali materi prasyarat dengan bertanya. Mengajukan pertanyaan yang ada keterkaitannya dengan pelajaran yang akan dilakukan. Memberikan gambaran tentang manfaat mempelajari pelajaran yang akan dipelajari. Apabila materi/tema/projek ini kerjakan dengan baik dan sungguh-sungguh ini dikuasai dengan baik, maka peserta didik diharapkan dapat menjelaskan tentang pengertian Data. Menyampaikan tujuan pembelajaran pada pertemuan yang berlangsung dan Mengajukan pertanyaan. Setelah itu Memberitahukan materi pelajaran yang akan dibahas pada pertemuan saat itu. Memberitahukan tentang kompetensi inti, kompetensi dasar, indikator, dan KKM pada pertemuan yang berlangsung. Pembagian kelompok belajar dan Menjelaskan mekanisme pelaksanaan pengalaman belajar sesuai dengan langkah-langkah pembelajaran. pertemuan yang berlangsung. Kemudian Pembagian kelompok belajar. Menjelaskan mekanisme pelaksanaan pengalaman belajar sesuai dengan langkah-langkah pembelajaran.

Dalam kegiatan inti Peserta didik diberi motivasi atau rangsangan untuk memusatkan perhatian pada topik Menafsirkan sebuah data dengan cara Melihat tanpa atau dengan alat Mengamati Lembar kerja, pemberian contoh-contoh materi/soal untuk dapat dikembangkan peserta didik, dari media interaktif, dsb yang berhubungan dengan Menafsirkan sebuah data. Membaca Dilakukan di rumah sebelum kegiatan pembelajaran berlangsung, materi dari buku paket atau buku-buku penunjang lain, dari internet/materi yang berhubungan denganMenafsirkan sebuah data. Pemberian materi oleh guru yang berkaitan dengan Menafsirkan sebuah data. Penjelasan pengantar kegiatan/materi secara garis besar/global tentang materi pelajaran mengenai Menafsirkan sebuah data untuk melatih kesungguhan, ketelitian, mencari informasi. Guru memberikan kesempatan pada peserta didik untuk mengidentifikasi sebanyak mungkin pertanyaan yang berkaitan dengan gambar yang disajikan dan akan dijawab melalui kegiatan belajar, contohnya Mengajukan pertanyaan tentang Menafsirkan sebuah data yang tidak dipahami dari apa yang diamati atau pertanyaan untuk mendapatkan informasi tambahan tentang apa yang diamati (dimulai dari pertanyaan faktual sampai ke pertanyaan yang bersifat hipotetik) untuk mengembangkan kreativitas, rasa ingin tahu, kemampuan merumuskan pertanyaan untuk membentuk pikiran kritis yang perlu untuk hidup cerdas dan belajar sepanjang hayat. Peserta didik mengumpulkan informasi yang relevan untuk menjawab pertanyan yang telah diidentifikasi melalui kegiatan. mengunjungi laboratorium komputer perpustakaan sekolah untuk mencari dan membaca artikel tentang Menafsirkan sebuah data. Di akhir pembelajaran guru memberitahu hasil ulangan pada siklus I, setelah itu guru memberikan pujian bagi siswa yang mencapai nilai KKM dan bagi siswa yang mendaptkan nilai ulangan harian tertinggi.

Pada akhir proses belajar mengajar, Peserta didik Membuat rangkuman/simpulan pelajaran.tentang pointpoint penting yang muncul dalam kegiatan pembelajaran yang baru dilakukan. Melakukan refleksi terhadap kegiatan yang sudah dilaksanakan. Sementara itu Guru Memeriksa pekerjaan siswa yang selesai langsung diperiksa. Peserta didik yang selesai mengerjakan projek dengan benar diberi paraf serta diberi nomor urut peringkat, untuk penilaian projek. Kemudian Memberikan penghargaan kepada kelompok yang memiliki kinerja dan kerjasama yang baik. Merencanakan kegiatan tindak lanjut dalam bentuk tugas kelompok/ perseorangan (jika diperlukan). Mengagendakan pekerjaan rumah. Menyampaikan rencana pembelajaran pada pertemuan berikutnya.

\section{Observasi}

Berikut ini adalah deskripsi data hasil pengamatan hasil belajar peserta didik di kelas SDN 137/IX Petaling pada siklus II. Adapun data hasil penelitian pada siklus II adalah sebagai berikut:

Tabel 2. Rekapitulasi Hasil Tes Formatif Pada Siklus II

\begin{tabular}{lll}
\hline No. & Uraian & Siklus II \\
\hline 1. & Nilai rata-rata tes formatif & 74,28 \\
2. & Jumlah peserta didik yang tuntas belajar & 23 \\
3. & Persentase ketuntasan belajar & $82,14 \%$ \\
\hline
\end{tabular}

\section{Ketuntasan Belajar Siklus II}

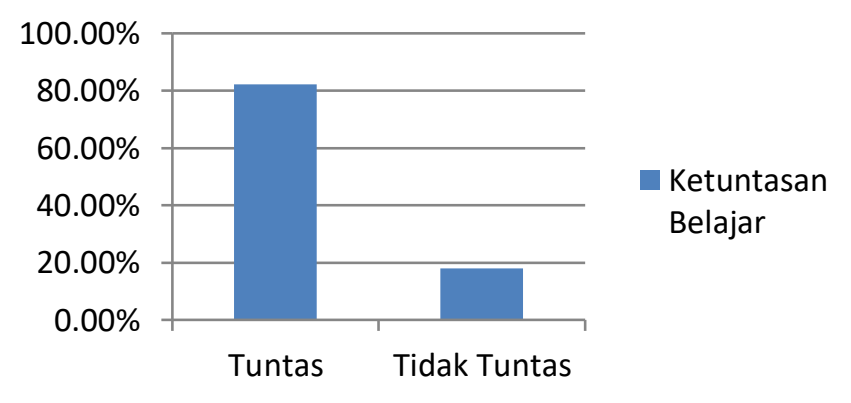

Gambar 2. Persentase Hasil Ketuntasan Belajar Siklus II

Dari tabel di atas dapat dijelaskan bahwa dengan menerapkan model pembelajaran Discovery Learning diperoleh nilai rata-rata hasil belajar peserta didik adalah 74,28 dan ketuntasan belajar mencapai $82,14 \%$ atau ada 23 peserta didik dari 28 peserta didik sudah tuntas belajar dan 5 siswa 17,86\% yang belum tuntas belajar. Hasil tersebut menunjukkan bahwa pada siklus kedua secara klasikal peserta didik sudah tuntas belajar, karena peserta didik yang memperoleh nilai $\geq 65$ sebesar 
$82,14 \%$ dan telah mencapai persentase ketuntasan yang dikehendaki yaitu sebesar $80 \%$. Hal ini disebabkan karena peserta didik sudah merasa mengerti apa yang dimaksudkan dan digunakan guru dengan menerapkan model pembelajaran Discovery Learning

\section{Pembahasan}

Berdasarkan hasil temuan pada siklus I dan Siklus II yang berkaitan dengan materi data dan pengukuran pada pembelajaran Matematika yaitu melalui hasil peneilitian ini menunjukkan bahwa model pembelajaran Discovery Learning memiliki dampak positif dalam meningkatkan hasil belajar siswa. Hal ini dapat dilihat dari semakin mantapnya pemahaman siswa terhadap materi yang disampaikan guru (ketuntasan belajar meningkat dari sklus I, dan II yaitu masing-masing 53,57 $\%$, dan 82,14 \%. Pada siklus II ketuntasan belajar siswa secara klasikal telah tercapai dan dengan adanya tindakan pemberian pujian. Hal ini sesuai dengan pendapat Sudjana (2004) bahwa hasil belajar siswa pada hakikatnya adalah perubahan tingkah laku sebagai hasil belajar dalam pengertian yang lebih luas mencakup bidang kognitif, afektif, dan psikomotorik.

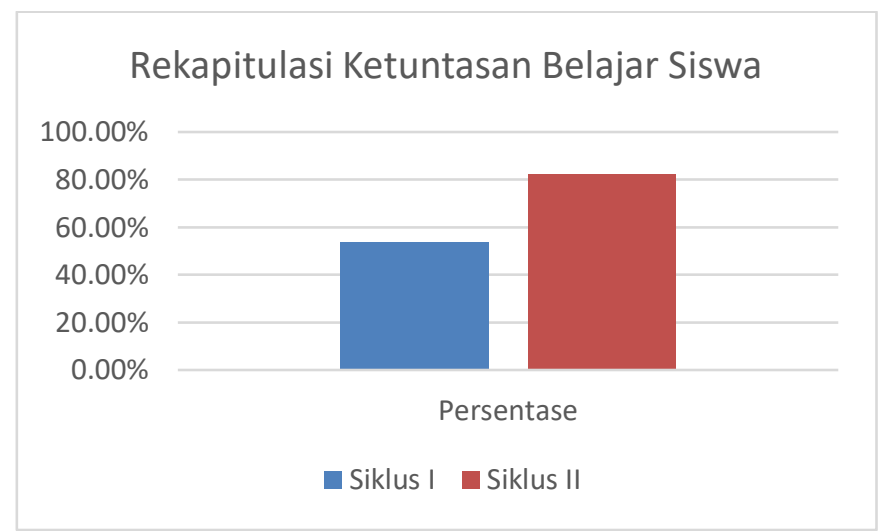

Gambar 3. Persentase Hasil Ketuntasan Belajar

\section{SIMPULAN}

Dari hasil kegiatan pembelajaran yang telah dilakukan selama dua siklus, dan berdasarkan seluruh pembahasan serta analisis yang telah dilakukan dapat disimpulkan sebagai berikut melalui hasil peneilitian ini menunjukkan bahwa model pembelajaran Discovery Learning dapat meningkatkan keterampilan materi pembelajaran data dan perhitungan. Hal ini dapat dilihat dari semakin mantapnya pemahaman siswa terhadap materi yang disampaikan guru (ketuntasan belajar meningkat dari siklus I, dan II yaitu masing-masing $53,57 \%$, dan $82,14 \%$. Pada siklus II ketuntasan belajar siswa secara klasikal telah tercapai dengan tindakan pemberian pujian.

\section{DAFTAR PUSTAKA}

Anni, Catharina Tri, dkk. 2004. Psikologi Belajar. Semarang: UPT UNNES Press.

Arikunto, Suharsimi. 2002. Prosedur Penelitian Suatu Pendekatan Praktek. Jakarta: Rineka Cipta

Depdiknas .2003. Undang-undang RI No.20 tahun 2003.tentang sistem pendidikan nasional.

Dimyati \& Mudjiono. 2013. Belajar Dan Pembelajaran. Jakarta: Rineka Cipta.

Hamalik, Oemar. 2001, Proses Belajar Mengajar.:

P.T. Bumi Aksara. Jakarta

Hamzah, 2007. Model Pembelajaran Menciptakan Proses Belajar Mengajar yang Kreatif dan Efektif. Jakarta Bumi Aksara.

Hosnan. 2014. Pendekatan Saintifik dan Kontekstual dalam Pembelajaran Abad 21.Bogor : Ghalia Indonesia.

Kusnandar. 2010. Langkah Mudah Penelitian Tindakan Kelas Sebagai Pengembangan Profesi Guru. : Raja Grafindo Persada. Jakarta

Piaget, Jean, \& Barbel Inhelder, 2010.Psikologi Anak, Terj. Miftahul Jannah, Yogyakarta : Pustaka Pelajar

Slameto. 2003. Belajar dan Faktor-faktor yang mempengaruhinya. : Rineka Cipta. Jakarta.

Sudirman 2004. Interaksi dan Motivasi Belajar Mengajar. : PT Raja Grafindo Persana Jakarta.

Sudjana, Nana. 2004. Dasar - dasar Proses belajar mengajar. :Sinar Baru Algensido Offset. Bandung.

Sumadi Suryabrata, 2003, Proses Belajar Mengajar di Perguruan Tinggi. Andi Offset. Yogyakarta.

Undang - undang Nomor 20 Tahun 2006 Tentang Sistem Pendidikan Nasional Media Pustaka Mandiri. Jakarta.

Warsita. 2008. Teknologi Pembelajaran Landasan Aplikasinya : Rineka Cipta.Jakarta. 